\title{
Detection of the Genotoxicity of Gentiana L. Extracts by Using RAPD-PCR and ISSR-PCR Techniques
}

\author{
İlham Eröz Poyraz ${ }^{1 *}$, İsmail Poyraz², H. Tuba Kıyan ${ }^{3}$, Nilgün Öztürk ${ }^{3}$ Serdar Erken ${ }^{4}$, Fatih Gülbağ ${ }^{4}$, \\ M. Ercan Özzambak \\ 1Department of Pharmaceutical Botany, Anadolu University, 26470 Eskişehir, TURKEY. \\ 2Department of Molecular Biology and Genetics, Bilecik Şeyh Edebali University, 11210 Bilecik, TURKEY. \\ ${ }^{3}$ Department of Pharmacognosy, Anadolu University, 26470 Eskişehir, TURKEY. \\ ${ }^{4}$ Republic of Turkey Ministry of Food, Agriculture and Livestock, Atatürk Horticultural Central Research Institute, Yalova, TURKEY. \\ ${ }^{5}$ Department of Horticulture, Ege University, 35100 İzmir, TURKEY.
}

\begin{abstract}
Backround: The RAPD- and ISSR-PCR techniques are offering an insight into the detecting the genotoxicity of Gentiana extracts. Objective: It is aimed with the present study, to detect the genotoxicity of methanol extracts of ten Turkish Gentiana L. taxa on germinated Allium cepa L. root tips. Methods: RAPD- and ISSR-PCR techniques were used for detection of genotoxicity of Gentiana extracts. Results: Four RAPD and three ISSR primers produced the reproducible polymorphic and monomorphic banding patterns among 10 RAPD and 10 ISSR primers for all DNA samples. It is not any serious alteration along with band intensity change, the disappearance of the bands, and appearance of the new bands in the band profiles amplified from the Gentiana extracts-treated genomic DNA sample of $A$. cepa. The most efficient results were obtained by RAPD-P9 and ISSR-1 primer among the seven productive primers. Discussion: It is not observed any variation in the RAPD- and ISSR-PCR band profiles in time and concentration-dependent manner. Conclusion: It is determined that the three different concentrations of Gentiana extracts did not interact with the $A$. cepa DNA.
\end{abstract}

Key words: Gentiana L., Genotoxicity, RAPD-PCR, ISSR-PCR.

\section{INTRODUCTION}

The genus Gentiana L. is a member of Gentianaceae which has world-wide distribution, but especially in temperate regions and about half the genera are grown in South America. The genus Gentiana L. is represented by 360 species all around the world. ${ }^{1}$ In Turkey the genus Gentiana is represented by 12 species and 14 taxa. $^{2}$ $G$. lutea L., officinal species, roots contain the secoiridoid glucosides which are bitter tasting. The roots are used for the treatment of liver complaints, indigestion, gastric infections, anorexia, wound healing, hepatoprotective and anti-inflammatory agents in all of the world. ${ }^{3,4}$ In Turkey, the roots are also used digestive system stimulant and appetizing, stimulate the red blood cells and against high fever, wound healing (external use of decoction)..$^{5-9}$ Mostly the aerial parts and roots contain xanthones, free or glycosidic flavonoids, alkaloids, iridoids, secoiridoids and also triterpenoids. ${ }^{410-12}$ The clastogenic agents cause lesions in the genetic material. The capacity of them called as genotoxicity. The damage in the DNA, mutations and chromosomal alterations are mainly evaluations of genotoxicity. Hence, the genotoxic agents possess the ability of alteration in DNA. The plant test system of Allium cepa, as a first screener of genotoxicity, is a model bioindicator. Intensely usages of medicinal plants for the treatment of diseases, it is required to investigate the toxicity potentials of them using in vivo test of A. cepa against to plant extracts due to their safe and efficient use. And so, the studies
Submission Date: 30-08-2016; Revision Date: 17-11-2016; Accepted Date: 23-11-2016

DOI: 10.5530/ijper.52.4s.89 Correspondence:

Dr. Illham Eröz Poyraz, Anadolu University, Faculty of Pharmacy, Department of Pharmaceutical Botany, 26470 Eskişehir/TURKEY

Phone: +902223350580/3707

E-mail: ieroz@anadolu.edu.tr

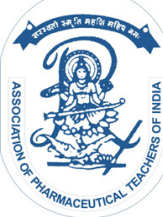

www.ijper.org 
based on $A$. cepa are helping to prevent damages of human health. ${ }^{13}$

Germinated Allium cepa roots were treated with methanol extracts of nine Turkish Gentiana species and RAPD- and ISSR-PCR techniques were used to detect the possibly genotoxicity of extracts on $A$. cepa genomic DNA within the present study.

\section{MATERIAL AND METHODS}

\section{Plant Materials}

The plants were collected from different localities of Turkey and the list for them is given in Table 1. The voucher specimens are deposited in the Herbarium of Atatürk Horticultural Central Research Institute.

\section{Extraction Procedure}

Air dried herba of Gentiana species (20 g) were crushed; macareted with $500 \mathrm{~mL} \mathrm{MeOH}$ using shaker incubator for $8 \mathrm{~h}$ (x3). The filtered extracts put together and concentrated using rotary evaporator at $40^{\circ} \mathrm{C}$.

\section{Genotoxicity Test Material and DNA Isolation}

Germinated Allium cepa roots were tested at three concentrations $(0.05,0.1$ and $0.5 \mathrm{mg} / \mathrm{mL}$ ) of ten Gentiana methanol extracts and control group for $72 \mathrm{~h}$ and then grounded in liquid nitrogen. The DNA isolation was carried out by using the DNA purification kit (EurX GeneMATRIX Plant and Fungi DNA Purification Kit). The quantity and quality of the DNA were determined by using a Nanodrop Spectrophotometer (Shimadzu, Japan). DNA samples were diluted with sterile distilled water to $2 \mathrm{ng} / \mu \mathrm{L}$.

\section{PCR Analysis with RAPD and ISSR Primers}

Gentiana extracts-treated $A$. cepa genome were amplified by PCR technique using RAPD and ISSR primers. RAPD-PCR amplifications were performed in $25 \mu \mathrm{L}$ of reaction mixture containing of template DNA, $1 \times$ Taq polymerase buffer and $1 \mathrm{U}$ of Taq polymerase (FIREPol, Solis BioDyne, Estonia), $\mathrm{MgCl}_{2}$, dNTPs (dATP, dCTP, dGTP, and dTTP) and primer (Table 2, 3). Amplifications were carried out in Thermo Arktik Thermal Cycler (Thermo Scientific, USA) that was programmed at Table 4. PCR reactions were repeated twice to ensure reproducibility of amplified products. The PCR products were simultaneously separated on the same agarose gel $(1.3 \%)$ containing ethidium bromide and photographed with the Gel Logic 212Pro imaging system (Carestream, USA). Molecular weights of PCR products were estimated using a $100 \mathrm{bp}$ DNA Ladder and 100 bp plus DNA Ladder (Fermentas, USA).

\begin{tabular}{c|c|}
\hline \multicolumn{2}{|c|}{ Table 1: Collected Gentiana taxa and localities. } \\
Plant Taxa & Collected from \\
\hline G. asclepiadea L. & Mount llgaz/Kastamonu \\
\hline G. cruciata L. & Mount llgaz/Kastamonu \\
\hline G. olivieri Griseb. & Nizip/Gaziantep \\
\hline G. pyrenaica L. & Zigana Passway/Gümüşhane \\
\hline $\begin{array}{c}\text { G. septemfida Pallas } \\
\text { G. boissieri Schott and } \\
\text { Kotschy ex Boiss. (endemic) }\end{array}$ & Soğanlı Passway/Bayburt \\
\hline G. gelida Bieb. & Mount Bolkar/Niğde \\
\hline $\begin{array}{c}\text { G. verna L. ssp. balcanica } \\
\text { Pritchard }\end{array}$ & Uludağ/Bursa \\
\hline $\begin{array}{c}\text { G. verna L. ssp. pontica } \\
\text { (Soltok.) Hayek }\end{array}$ & Soğanlı Passway/Bayburt \\
\hline $\begin{array}{c}\text { G. brachyphylla Vill. ssp. } \\
\text { favratii (Rittener) Tutin }\end{array}$ & Mount Bolkar/Niğde \\
\hline
\end{tabular}

\begin{tabular}{|c|c|}
\hline Contents & Volume \\
\hline $\mathrm{dH}_{2} \mathrm{O}$ & $11.8 \mu \mathrm{L}$ \\
\hline $10 \times$ TaqBuffer (Fermantas) & $2.5 \mu \mathrm{L}(1 \mathrm{x})$ \\
\hline $25 \mathrm{mM} \mathrm{MgCl}_{2}$ (Fermantas) & $1.5 \mu \mathrm{L}(1.5 \mathrm{mM})$ \\
\hline $2.5 \mathrm{mM}$ dNTP (Fermantas) & $2 \mu \mathrm{L}(0.2 \mathrm{Mm})$ \\
\hline $2.5 \mu \mathrm{M}$ Primer & $4 \mu \mathrm{L}(0.4 \mu \mathrm{M})$ \\
\hline Templete DNA & $3 \mu \mathrm{L}$ \\
\hline TaqPolimerase (Fermantas) & $0.2 \mu \mathrm{L}$ \\
\hline Total & $25 \mu \mathrm{L}$ \\
\hline
\end{tabular}

\begin{tabular}{|c|c|c|c|}
\hline \multicolumn{4}{|c|}{ Table 3: RAPD-PCR application procedure. } \\
\hline & Cycle(s) & Temperature $\left({ }^{\circ} \mathbf{C}\right)$ & Time \\
\hline Initial Denaturation & 1 & 95 & $4 \mathrm{~min}$ \\
\hline Denaturation & & 94 & $55 \mathrm{sec}$ \\
\hline Annealing & 45 & $30-34$ & $60 \mathrm{sec}$ \\
\hline Extention & & 72 & $90 \mathrm{sec}$ \\
\hline Final Extention & 1 & 72 & $7 \mathrm{~min}$ \\
\hline
\end{tabular}

\begin{tabular}{|c|c|}
\hline \multicolumn{2}{|c|}{ Table 4: ISSR-PCR contents and volumes. } \\
\hline Contents & Volume \\
\hline $\mathrm{dH}_{2} \mathrm{O}$ & $13.3 \mu \mathrm{L}$ \\
\hline 10X TaqBuffer (Fermantas) & $2.5 \mu \mathrm{L}(1 \mathrm{x})$ \\
\hline $25 \mathrm{mM} \mathrm{MgCl}$ (Fermantas) & $1.5 \mu \mathrm{L}(1.5 \mathrm{mM})$ \\
\hline $2.5 \mathrm{mM} \mathrm{dNTP}$ (Fermantas) & $2 \mu \mathrm{L}(0.2 \mathrm{mM})$ \\
\hline $2.5 \mu \mathrm{M}$ Primer & $2,5 \mu \mathrm{L}(0.25 \mu \mathrm{M})$ \\
\hline Templete DNA & $3 \mu \mathrm{L}$ \\
\hline TaqPolimerase (Fermantas) & $0.2 \mu \mathrm{L}$ \\
\hline Total & $25 \mu \mathrm{L}$ \\
\hline
\end{tabular}




\begin{tabular}{|c|c|c|c|}
\hline \multicolumn{4}{|c|}{ Table 5: ISSR-PCR application procedure. } \\
\hline & Cycle(s) & Temperature ( $\left.^{\circ} \mathbf{C}\right)$ & Time \\
\hline Initial Denaturation & 1 & 95 & $4 \mathrm{~min}$ \\
\hline Denaturation & & 94 & $45 \mathrm{sec}$ \\
\hline Annealing & 45 & $49.2-60.5$ & $45 \mathrm{sec}$ \\
\hline Extention & & 72 & $90 \mathrm{sec}$ \\
\hline Final Extention & 1 & 72 & $7 \mathrm{~min}$ \\
\hline
\end{tabular}

\section{Table 6: RAPD primers tested for amplification of A. cepa genomic DNA.}

\begin{tabular}{|c|c|c|c|}
\hline Tested Primers & Primer sequence (5'-3') & Tm $\left({ }^{\circ} \mathbf{C}\right)$ & Appositeness \\
\hline OPC-04 & CCGCATCTAC & $\mathbf{3 2}$ & + \\
\hline OPC-07 & GTCCCGACGA & $\mathbf{3 4}$ & $\mathbf{+}$ \\
\hline P-9 & GGGAAGAGAG & $\mathbf{3 2}$ & + \\
\hline P-11 & GGCCGATGAT & 32 & - \\
\hline P-13 & ACCGCCTTGT & 32 & - \\
\hline P-14 & CAGCACTGAC & 32 & - \\
\hline P-16 & TGGTGGCCTT & 32 & - \\
\hline P-17 & GTAGCACTCC & 32 & - \\
\hline P-21 & ACGGTGCCTG & 34 & - \\
\hline OPD-09 & CTCTGGAGAC & 32 & + \\
\hline
\end{tabular}

Amplification of ISSR fragments from $A$. cepa genomic DNA was performed in a total reaction volume of $25 \mu \mathrm{l}$ containing of template DNA, 1X Taq polymerase reaction buffer, $\mathrm{MgCl}_{2}$, dNTPs, primer and $1 \mathrm{U}$ of Taq DNA polymerase (FIREPol, Solis BioDyne) (Table 4). Amplifications were performed in Thermo Arktik Thermal Cycler (Thermo Scientific). 4 min initial denaturation at $95^{\circ} \mathrm{C}$ and 1 cycle, 45 cycles of $45 \mathrm{sec}$. denaturation at $94^{\circ} \mathrm{C}, 50 \mathrm{sec}$ annealing at $49.2-60.5^{\circ} \mathrm{C}$ (primer depended) for ISSR amplification, and a $90 \mathrm{sec}$ extension at $72^{\circ} \mathrm{C}$, followed by a final extension at $72^{\circ} \mathrm{C}$ for $7 \mathrm{~min}$ (Table 5). PCR-amplified fragments were separated on 1.3\% agarose gel containing ethidium bromide. Gels were visualized under UV light and digitally photographed with Gel Logic 212Pro imaging system (Carestream). Molecular weights of ISSR-PCR products were estimated using $100 \mathrm{bp}$ DNA Ladder and 100 bp plus DNA Ladder (Fermentas).

RAPD analysis was performed according to the method of Williams et al..$^{14} \mathrm{~A}$ set of 10 random 10-mer primers was purchased from Thermo Inc. (Burlington, MA, USA) and an initial primer screening was carried out for selection of suitable primers. After screening, four primers amplified clear, reproducible banding patterns were used for further analysis (Table 6).

ISSR analysis was performed according to the method of Wongsawad and Peerapompisal. ${ }^{15} \mathrm{~A}$ set of 10 random 10-mer primers was purchased from Thermo Inc.
(Burlington, MA, USA) and an initial primer screening was carried out for selection of suitable primers. Two primers amplified clear, reproducible banding patterns and used for further analysis (Table 7).

Gel photographs evaluated with the SynGene-Gene Tools (Cambridge, UK) software. The band profiles of primers and similarity matrix analysis were performed using SynGene-Gene Tools.

\section{RESULTS AND DISCUSSION}

The primers RAPD-OPC 04, RAPD-OPC 07, RAPDOPD 09, RAPD-P9, ISSR-01 and ISSR-847 were amplified clear, reproducible banding patterns after the PCR analysis. The most reproducible banding patterns were obtained from RAPD-P9 (Figure 1) and ISSR-1 (Figure 2). The results were supported also by other primers (RAPD-OPC 04, RAPD-OPC 07, RAPD-OPD 09, and ISSR-847) but RAPD-OPC 04, RAPD-OPD 09, and ISSR- 847 were the minority of reproducible banding patterns than the rest ones. The last three primers -RAPD-OPC 04, RAPD-OPD 09, ISSR-847 were not only amplified intraspecific species-specific, but also a lot of non-specific banding patterns, it is obvious that these primers are the least reproducible ones.

The band profiles of the RAPD-P9 (Figure 3) and ISSR 1 (Figure 4) were performed using SynGene-Gene Tools software. Due to the PCR samples were simul- 
Table 7: ISSR primers tested for amplification of A. cepa genomic DNA.

\begin{tabular}{|c|c|c|c|}
\hline \multicolumn{2}{|c|}{ Table 7: ISSR primers tested for amplification of A. cepa genomic DNA. } \\
\hline Tested Primers & Primer sequence (5'-3') & Tm $\left({ }^{\circ} \mathbf{C}\right)$ & Appositeness \\
\hline ISSR-01 & AGAGAGAGAGAGAGAGG & $\mathbf{5 2 . 8}$ & + \\
\hline ISSR-04 & ACACACACACACACACC & 52.8 & - \\
\hline ISSR-06 & GAGAGAGAGAGAGAGAC & 52.8 & - \\
\hline ISSR-10 & GGGTGGGTTGGGGTG & 58.8 & - \\
\hline ISSR-27 & GTGCGTGCGTGCGTGC & 59.4 & - \\
\hline ISSR-829 & TCTCTCTCTCTCTCTCG & 52.8 & - \\
\hline ISSR-847 & CACACACACACACACARC & $\mathbf{5 3 . 7}$ & - \\
\hline ISSR-861 & ACCACCACCACCACCACC & 60.5 & - \\
\hline ISSR-862 & AGCAGCAGCAGCAGCAGC & 60.5 & - \\
\hline ISSR-866 & CTCCTCCTCCTCCTCCTC & 60.5 & \\
\hline
\end{tabular}

taneously run on the same agarose gel, the gel image of samples after the $9-0.1 \mathrm{mg} / \mathrm{mL}$ sample (20. well) is darker. Therefore, some bands of the samples after the twentieth well are invisible.

Depend on the applied concentrations $(0.05,0.1$ and $0.5 \mathrm{mg} / \mathrm{mL}$ ) and ignorance of the non-specific banding patterns, the Gentiana extracts have not caused serious band changing within the intraspecific species-specific bands. For the RAPD-P9 primer, the highest concentration $(0.5 \mathrm{mg} / \mathrm{mL})$ of the banding patterns of 1 th, 6th, 8th and 9th extracts (G. pyrenaica, G. boissieri, $G$. septemfida and $G$. verna ssp. balcanica) thinking the DNA damage due to the band changing. But the comparison to ISSR-1 primer amplification results, the species specific-banding patterns were preserved and there was no band changing for the mentioned extracts. Many studies report that the RAPD/ISSR PCR assays are more sensitive than classic tests such as comet, micronucleus assay due to detecting the temporary DNA changes. RAPD-PCR technique has been used successfully to detect various types of DNA change/ damages/mutations in organisms induced by various types of contaminants, ${ }^{16-20}$ pollutants. ${ }^{21-23}$ Bajpai et $a .^{24}$ Bakry et al. ${ }^{25}$ and Zietkiewicz et al. ${ }^{26}$ used ISSRPCR technique for investigation of genotoxicity. Along with these studies, it is declared that due to the interaction within contaminants/pollutants/plant extracts and DNA, detecting the changes in the number, position and intensity of DNA bands gave the genotoxicity through DNA damage. There are some studies detecting the genotoxic effects of plant extracts on plant agents. It was reported that changings occurred in RAPD profiles of Zea mays seeds treated with Verbascum speciosum extract included variation in band intensity, loss of bands and appearance of new bands compared with control. ${ }^{27}$ According to another previous study,

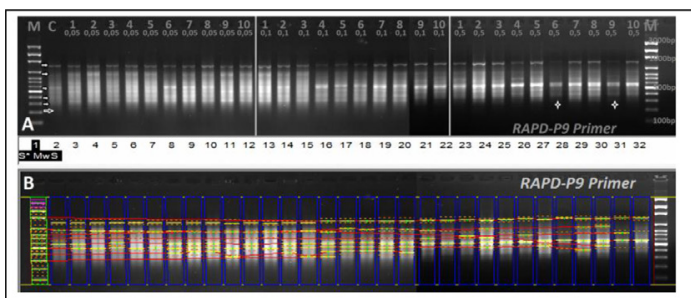

Figure 1A: Gel photographs of amplified PCR banding patterns of $A$. cepa root tip genome with RAPD-P9 primer. A- M:

100 bp DNA marker; C: Control group; 1-10: Methanol extracts of G. pyrenaica, G. brachyphylla, G. olivieri, G. cruciata, G. asclepiadea, G. boissieri, G. gelida, G. septemfida, G. verna ssp. balcanica, G. verna ssp. pontica; NC: Negative control; White filled arrow: Preserved band; Unfilled arrow: Non-specific band; Star: Band changing, B- Gel photographs evaluated with the SynGene-Gene Tools software, Yellow lines: preserved bands, Red lines: partial preserved bands. B. The primer gel photograph evaluated with the SynGeneGene Tools File Version software.

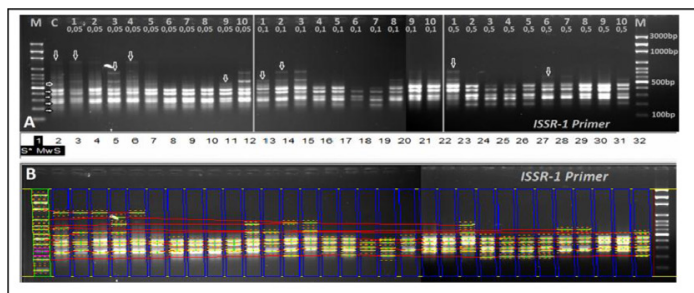

Figure 2: Gel photographs of amplified PCR banding patterns of $A$. cepa root tip genome with ISSR-1 primer. A- M: $100 \mathrm{bp}$

DNA marker; C: Control group; 1-10: Methanol extracts of G. pyrenaica, G. brachyphylla, G. olivieri, G. cruciata,

G. asclepiadea, G. boissieri, G. gelida, G. septemfida, G. verna ssp. balcanica, G. verna ssp. pontica; NC: Negative control; White filled arrow: Preserved band; Unfilled arrow: Non-specific band; Star: Band changing, B- Gel photographs evaluated with the SynGene-Gene Tools software, Yellow lines: preserved bands, Red lines: partial preserved bands. B. The primer gel photograph evaluated with the SynGene-Gene Tools File Version software. 


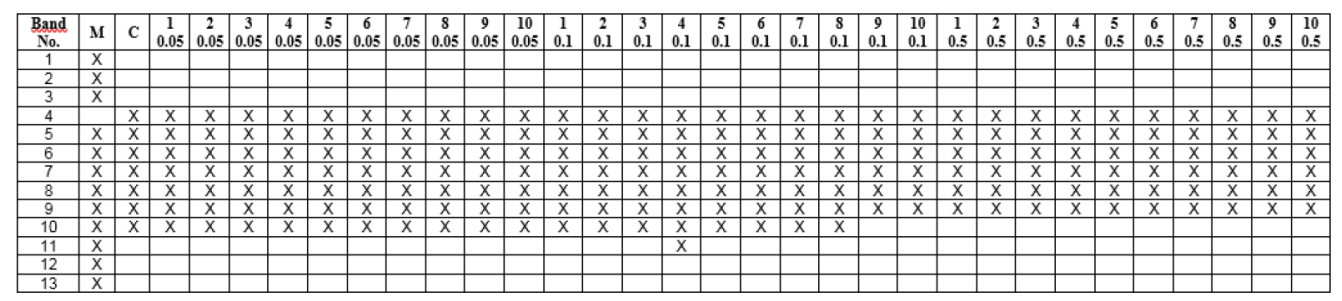

Figure 3: RAPD-P9 primer band profiles obtained using SynGene-Gene Tools.

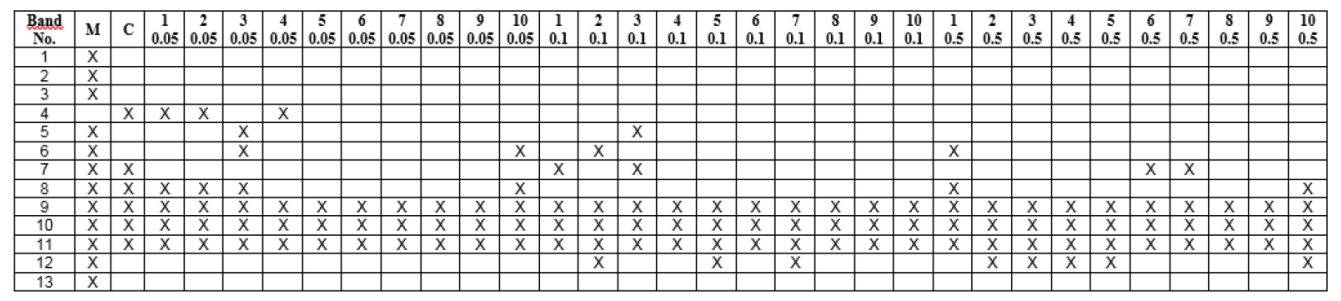

Figure 4: ISSR-1 primer band profiles obtained using SynGene-Gene Tools.

some changes were reported to occur in RAPD profiles of germinated Nepeta nuda essential oil-treated Z. mays seeds. ${ }^{28}$ Protein bands and RAPD analyses of $V$. faba treated with three Dipterygium glaucum extracts revealed some newly induced proteins and DNA fragments and other disappeared. ${ }^{29}$ These studies support that RAPD/ISSR-PCR analysis could be applied as a suitable biomarker assay for the detection of genotoxic effects of plant extracts.

\section{CONCLUSION}

Evaluated RAPD and ISSR-PCR amplification patterns are determined that the three different concentrations of ten Turkish Gentiana taxa methanol extracts did not interact within the $A$. cepa DNA. The usage of RAPD and ISSR primers for detecting the plant extracts genotoxicity on plant test systems are gave preliminary but predictable and noteworthy outcomes.

\section{ACKNOWLEDGEMENT}

This study was supported by Anadolu University Scientific Investigation Projects Commission [Grant number: 1508S584]. Also, this study is a part of the doctorate thesis done by Kiyan, H.T. and titled as "Pharmacognostical investigations on some Gentiana taxa", Anadolu University, Graduate School of Health Sciences, Eskişehir, 2017.

\section{CONFLICT OF INTEREST}

The authors declared that there is no conflict of interest in this research.

\section{ABBREVIATIONS}

DNA: Deoxyribonucleic acid; RAPD-PCR: Random Amplified Polymorphic DNA-Polymerase Chain Reaction; ISSR-PCR: Inter Simple Sequence Repeat- Polymerase Chain Reaction.

\section{REFERENCES}

1. Stevens PF. Angiosperm Phylogeny Website. 2001 Version 14, July 2017 [and continuously updated since]." will do. http://www.mobot.org/MOBOT/ research/APweb/. (accessed 11.10.2017).

2. Davis PH. Flora of Turkey and the East Aegean Islands, Edinburgh University Press. Edinburgh. 1978;6:176.

3. Šavikin K, Jankovic T, Krstić-Miloŝević D, Menković N, Milosavljević S. Secondary Metabolites and Biological Activities of some Gentianaceae species from Serbia and Montenegro, In: Gupta VK, Taneja SC, Gupta BD. Comprehensive Bioactive Natural Products. Extraction, Isolation and Characterization. TX, USA: Studium Press LLC. 2010;6. (ProQuest ebrary. Web. 17 February 2015).

4. Pan Y, Zhao YL, Zhang J, Li WL, Wang YZ. Phytochemistry and pharmacological activities of the genus Gentiana (Gentianaceae), Chemistry and Biodiversity. 2016;13(2):107-50.

5. Baytop T. Türkiye'de Bitkiler ile Tedavi, Geçmişte ve Bugün. İstanbul: Nobel Tıp Kitabevleri. 1999.

6. Başer KHC. Centiyane kökü, Bağbahçe. 2016;64:26-27.

7. Orhan DD, Aslan M, Aktay G, Ergun E, Yeşilada E, Ergun F. Evaluation of hepatoprotective effect of Gentiana olivieri herbs on subacute administration and isolation of active principle. Life Sciences. 2003;72(20):2273-83.

8. Öztürk N, Herekman-Demir T, Öztürk Y, Bozan B, Başer KHC. Choleretic activity of Gentiana lutea ssp. symphyandra in Rats, Phytomedicine. 1998;5(4):283-8.

9. Öztürk N, Korkmaz S, Öztürk $\mathrm{Y}$, Başer KHC. Effects of gentiopicroside, sweroside and swertiamarine, secoiridoids from gentian (Gentiana lutea ssp. symphyandra), on cultured chicken embryonic fibroblasts. Planta Medica. 2006;72(4): 289-94.

10. Jensen SR, Schripsema J. Chemotaxonomy and pharmacology of Gentianaceae. In: Struwe L, Albert VA. (Eds.), Gentianaceae - Systematics and Natural History. Cambridge, New York, Cambridge: University Press. 2002. 
11. Kušar A, Zupančič A, Šentjurc $M$, Baričevič D. Free radical scavenging activities of yellow gentian (Gentiana lutea L.) measured by electron spin resonance. Human and Experimental Toxicology. 2006;25(10):599-604.

12. Wu QX, Li Y, Shi YP. Antioxidant phenolic glucosides from Gentiana piasezkii. J Asian of Natural Products Research. 2006;8(3):391-6.

13. Tedesco SB, Laughinghouse IV HD. Bioindicator of genotoxicity: The Allium cepa test. In: Environmental Contamination. 2012. InTech.

14. Williams JGK, Kubelik AR, Livak KJ. DNA polymorphisms amplified by arbitrary primers are useful as genetic markers. Nucleic Acids Research. 1990;18(22):6531-5.

15. Wongsawad P, Peerapornpisal $\mathrm{Y}$. Molecular identification and phyto-genetic relationship of green algae, Spirogyra ellipsospora (Chlorophyta) using ISSR and rbcL marker, Saudi. Journal of Biological Sciences. 2014;21(5):505-10.

16. Liu W, Li PJ, Qi XM, Zhou QX, Zheng L, Sun TH. DNA changes in barley (Hordeum vulgare) seedlings induced by cadmium pollution using RAPD analysis. Chemosphere. 2005;61(2):158-67.

17. Enan MR. Application of random amplified polymorphic DNA (RAPD) to detect the genotoxic effect of heavy metals. Biotechnology and Applied Biochemistry. 2006;43(3):147-54.

18. Cenkçi S, Yıldız M, Ciğerci IH, Konuk M, Bozdağ A. Toxic chemicals-induced genotoxicity detected by random amplified polymorphic DNA (RAPD) in bean (Phaseolus vulgaris L.) seedlings. Chemosphere. 2009;76(7):900-6.

19. Aslam R, Ansari MYK, Choudhary S, Bhat TM, Jahan N. Genotoxic effects of heavy metal cadmium on growth, biochemical, cyto-physiological parameters and detection of DNA polymorphism by RAPD in Capsicum annuum L. An important spice crop of India. Saudi Journal of Biological Sciences. 2014;21(5):465-72.

20. Salem ZB, Capelli N, Grisey E, Baurand PE, Ayadi H, Aleya L. First evidence of fish genotoxicity induced by heavy metals from land fill leachates:
The advantage of using the RAPD-PCR technique. Ecotoxicology and Environmental Safety. 2014;101:90-6.

21. Atienzar FA, Jha AN. The random amplified polymorphic DNA (RAPD) assay and related techniques applied to genotoxicity and carcinogenesis studies: A critical review. Mutation Research. 2006;613(2):76-102.

22. Zhou L, Li J, Lin X, Al-Rasheid KAS. Use of RAPD to detect DNA damage induced by nitrofurazone in marine ciliate, Euplotes vannus (Protozoa, Ciliophora). Aquatic Toxicology. 2011;103(3):225-32.

23. Nan P, Xia X, Du Q, Chen J, Wu X, Chang Z. Genotoxic effects of 8-hydroxylquinoline in loach (Misgurnus anguillicaudatus) assessed by the micronucleus test, comet assay and RAPD analysis. Environmental Toxicology and Pharmacology. 2013;35(3):434-43.

24. Bajpai R, Shukla V, Singh N, Rana TS, Upreti DK. Physiological and genetic effects of chromium $(+\mathrm{VI})$ on toxitolerant lichen species, Pyxine cocoe. Environmental Science and Pollution Research. 2015;22(5):3727-38.

25. Bakry FA, Ismail SM, El-Atti MSA. Glyphosate herbicide induces genotoxic effect and physiological disturbances in Bulinus truncatus snails. Pesticide Biochemistry and Physiology. 2015;123:24-30.

26. Zietkiewicz E, Rafalski A, Labuda D. Genome fingerprinting by simple sequence repeat (SSR)-anchored polymerase chain reaction amplification. Genomics. 1994;20:176-83.

27. Sunar S, Aksakal O, Yıldırım, N, Ağar G. Determination of the genotoxic effects of Verbascum speciosum Schrad. extracts on corn (Zea mays L.) seeds. Romanian Biotechnological Letters. 2009;14(6):4820-6.

28. Bozarı S, Ağar G, Aksakal O, Ertürk FA, Yanmış D. Determination of chemical composition and genotoxic effects of essential oil obtained from Nepeta nuda on Zea mays seedlings. Toxicology and Industrial Health. 2013;29(4):339-48.

29. Altwaty NH, El-Sayed OE, Aly NAH, Baeshen MN, Baeshen N. Molecular and cytogenetic assessment of Dipterygium glaucum genotoxicity. Anais da Academia Brasileira de Ciências. 2016;88:623-34.

\section{PICTORIAL ABSTRACT}

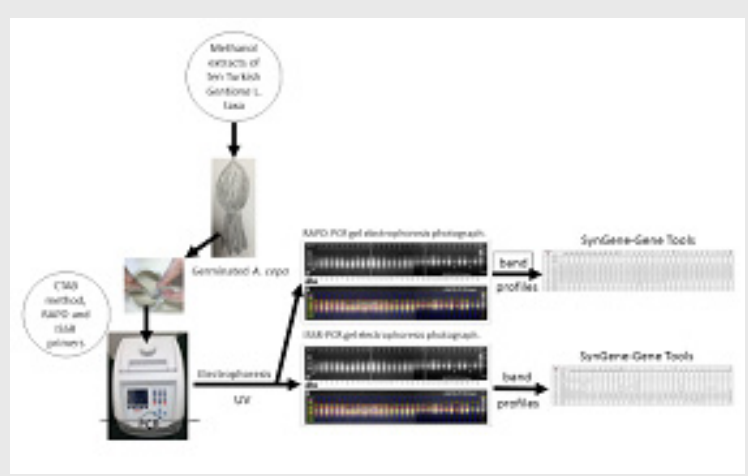

\section{SUMMARY}

- Evaluation of the PCR amplification patterns, within the used primers, it is not detected any genotoxicity on A. cepa genome treated with Gentiana extracts.

\section{About Authors}

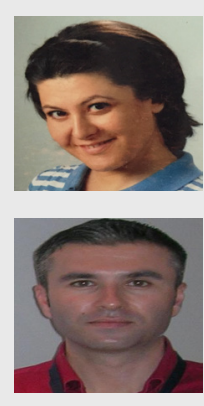

Ilham Eroz Poyraz: Is presently working as Assistant Professor Doctor in the Department of Pharmaceutical Botany in Faculty of Pharmacy, Anadolu University. Her experiences in the area are medicinal plants, ethnobotany, plant morphology and anatomy.

Ismail Poyraz: Is presently working as Assistant Professor Doctor in the Department of Molecular Biology and Genetics Faculty of Science and Letter, Bilecik Seyh Edebali University, His working subjects are molecular genetics, molecular systematics, and biotechnology. 


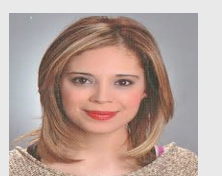

H. Tuba Kiyan: Is presently working as Research Assistant Doctor in the Department of Pharmacognosy in Anadolu University, Faculty of Pharmacy. Her experience in the area are pharmacognosy, phytochemistry, antioxidant and enzyme inhibition activities.

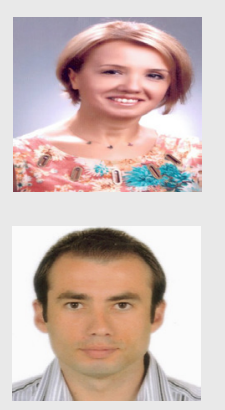

Nilgun Ozturk: Is presently working as Professor Doctor in the Department of Pharmacognosy in Anadolu University, Faculty of Pharmacy. Her experience in the area are pharmacognosy, phytochemistry, polyphenols, antioxidant activity, cytotoxicity, enzyme inhibition activities, antiAlzheimer activity.

Serdar Erken: Is presently working as Doctor in the Atatürk Horticultural Central Research Institute. His experience in the area are ornamental plants growing and breeding.

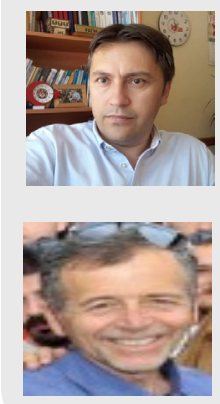

Fatih Gulbag: Is presently working as Doctor in the Atatürk Horticultural Central Research Institute. His experience in the area are ornamental plants growing and breeding.

M. Ercan Ozzambak: Is presently working as Professor Doctor in the Department of Horticulture in Faculty of Agriculture, Ege University. His experience in the area are ornamental plants growing, breeding and tissue culture.

Cite this article: Eroz Poyraz I, Poyraz I, Kiyan HT, Öztürk N, Erken S, Gülbag F, Özzambak ME. Detection of the Genotoxicity of Gentiana L. Extracts by Using RAPD-PCR and ISSR-PCR Techniques. Indian J of Pharmaceutical Education and Research. 2018;52(4S):S133-S139. 